\title{
FAMILY EDUCATION VALUES IN KIRANA KEJORA'S NOVELS (GENETIC STRUCTURAL RESEARCH)
}

\author{
Wulan Wahyuning Ratri \\ Language Education, Postgraduate of Universitas Negeri Jakarta, Indonesia \\ E-mail:wulanwahyura@gmail.com \\ Emzir \\ Language Education, Postgraduate of Universitas Negeri Jakarta, Indonesia \\ E-mail: emzir.unj@unj.ac.id \\ Ninuk Lustyantie \\ Language Education, Postgraduate of Universitas Negeri Jakarta, Indonesia \\ E-mail: ninuk.lustyantie@unj.ac.id
}

\begin{abstract}
APA Citation: Ratri, W. W., Emzir., \& Lustyantie, N. (2017). : Family education values in Kirana Kejora's novels (Genetic structural research). English Review: Journal of English Education, 5(2), 263-274
\end{abstract}

Received: 11-04-2017

Accepted: 21-05-2017

Published: 01-06-2017

\begin{abstract}
The objective of this research is to acquire deep understanding about family education values in the novels by Kirana Kejora through genetic structural. It was a qualitative research with content analysis method. This research was analyzed through structural literary approach and genetic structural approach. The data were collected through document study, data observation about family education values in the novels by Kirana Kejora (Bintang Anak Tuhan, Air Mata Terakhir Bunda, Ayah Menyayangi Tanpa Akhir), and interview with Kirana Kejora. The result of this research revealed that family education values that were founded and described in the novels by Kirana Kejora were diligent to worship, honest, respect, unanimous, having achievement, mandate, brave, independent, proportional, take care of self, affection, prelude other people, and fair. They were founded and described through intrinsic structure of novel, author's background, social background, and author's world view. Those results lead to implication that Indonesian literature educator can use Kirana Kejora's novels directly in the teaching process. Further, the findings lead to recommendation to Indonesian literature educators in order to use novels with content of family education values and to motivate students to analyze the novels through genetic structural.
\end{abstract}

Keywords: family education values, novel, genetic structural

\section{INTRODUCTION}

In teaching literature, warmth can be created by the content of literature teaching itself, for instance, the content of literature teaching which encouraging values of family education. The learners who are able to respect the literature learning process are them who come from the families which are fully filled by values of family education. Therefore, it becomes the researcher's reason for conducting the research about the values of family education relating to literature aspect. Helmawati (2014, p. 50) explains that in family environment, for the first time, the children get some values. If children are raised with the good values of family education, they will learn to respect others, including respecting literature teachers and their literary works.

Railton (2003, p. 45) states that values can be understood as something that has a norm taste. It means, if the values has a norm taste, the values can be considered for having positive sides, including the family education. 
Related to the values of family education, it is observed that the values in literature have been taught in formal school, especially in grade XI and XII, as what have been summarized by Syafrial (2014, pp. 73-75) who describes that in teaching literature, the values of literary works consisting of hedonic, artistic, cultural, ethical, moral, religion, and education values were taught and analyzed. Based on that condition, the researcher assumes that the analysis of educational values in novels examined by the students or college students are still low. Educational values haven't referred to family education value which directly contributes to literature teaching. Literature teaching will be able to be accepted well by students or college students if there are high enthusiasms. High enthusiasm can be based on either students or college students who are taught to respect by their parents.

In Indonesia, the novel authors carry some kinds of novels. Family education values are also carried by the authors, including Kirana Kejora, as can be found in her novels entitled Bintang Anak Tuhan, Air Mata Terakhir Bunda, and Ayah Menyayangi Tanpa Akhir. Those three novels might not relate one to another, but they carry the same theme about family. As for, Kirana Kejora is familiar to family life. Kirana Kejora's three novels (Bintang Anak Tuhan, Air Mata Terakhir Bunda, Ayah Menyayangi Tanpa Akhir) are chosen as the data source of the research since they contain humanity aspects. Those three novels are also focused on parents and children. By the facts, the researcher decides to analyze the values of family education in those novels.

Kirana Kejora's novels contain values of family education, relate to reality, so it can be analyzed through genetic structural approach. Endraswara (2008, p. 60) states that genetic structural approach should, at least, have three aspects. The aspects are literature intrinsic, background of the creator, and social background. The author's world view is also included. Based on those things, the researcher views that Kirana Kejora's novels are worth and important to be analyzed.

Novels are best known as fiction. It is supported by Eagleton (1996, p. 2) who states that if literature includes much factual writing, it also excludes quite a lot of fiction. It means that the fiction sides in novels have good purposes to touch the readers' soul. Beside known as fiction, novels also can relate to realities. Stanton (2007, p. 8) states that novels can show human experiences, even the author's experiences. One of human experiences can have relation with the values of family education. Lestari (2014, pp. 168-171) states that values of family education consist of diligent to worship, honest, respect, unanimous, and having achievement. In line with Lestari, Syamsi translated by Mujtahid (2014, pp. 97-114) explains that values of family education consist of having Prophetmoral, mandate, brave, good in interaction, independent, proportional, take care of self, fulfilling promises, honor, affection, prelude other people, polite, and fair. The values of family education is instilled since people were still children until they become adults. The researcher decides to analyze thirteen values of family education in Kirana Kejora's novels, involving diligent to worship, honest, respect, unanimous, having achievement, mandate, brave, independent, proportional, take care of self, affection, prelude other people, and fair.

Furthermore, the researcher uses literary structural approach and genetic structural approach. Dosse (1998, p. 78) states that whatever the case, structuralism is a serious thing, as we have seen. It gives anything have to do with signs a right to sentence. It means, with the literary structural approach, the researcher will have deeper knowledge about the story in novels. Moreover, on genetic structural approach, as what have been stated by Goldmann (1977, p. $158)$, the creation of literary works is about linking literary works with social groups. 
Therefore, it can be observed that novel not only reflects individuals, but also society. In genetic structural approach, things about author's background, social background, and even the author's world view are considered. The author's background is considered through genetic structural approach since there are always the author's intervention, thoughts, and feelings in literary works (Endraswara, 2011, p. 102).Regarding the social background, Goldmann (1977, p. 159) explains that the author is faced with some social awareness and facts; the author observes social facts. On the other hand, the author's world view influences human behaviors. Endraswara (2012, p. 137) explains that points of view can refer to the author's views about his or her own world and society.

In brief, the focus of the research is analyzing values of family education in Kirana Kejora's novels reviewed through genetic structural approach. From the focus, the researcher formulates the five following research questions; how the values of family education in Kirana Kejora's novels reviewed through: (1) intrinsic structure of the novels?, (2) author's background?, (3) social background?, (4) author's world view?, (5) the comparison of family education values between the three Kirana Kejora's novels?. Based on those research questions, it can be known that the objective of this research was to get comprehension deeply about the values of family education in Kirana Kejora's novels through genetic structural approach. The scopes involve novel intrinsic structure, author's background, social background, author's world view, and also comparison of family education values between the three Kirana Kejora's novels.

\section{METHOD}

This research is conducted from September 2015 until September 2016 through content analysis method. Literary approaches used are structural approach and literary structural approach. The data were then collected through literature review, observing things related to family education values in novels, and structured interview. Therefore, there are two kinds of data, namely primary and secondary data. The novels by Kirana Kejora entitled Bintang Anak Tuhan, Air Mata Terakhir Bunda, and Ayah Menyayangi Tanpa Akhir are used as primary data sources. Whereas, the secondary data consist of interview transcription and internet articles about Kirana Kejora's novels.

In this research, there are seven steps of data collecting techniques, including: (1) reading Kirana Kejora's novels, (2) finding unique and worthy phenomena to be analyzed, (3) setting the values of family education as research data, (4) setting the three Kirana Kejora's novels as data sources, (5) setting content analysis as research method, (6) settingstructural approach and genetic structural approach as research approaches, (7) doing literature review, observation of things referring to the values of family education in Kirana Kejora's novels, and interviews. Data validity is tested by interviewing the author and reviewing the supporting articles.

Furthermore, the data analysis procedures in this research are as follows: (1) finding, selecting, and clarifying the intrinsic structure of the three novels, (2) analyzing the family education values in novels by reviewing the novels' intrinsic structure, (4) making a working table related to recapitulation numbers of data observing family education values in novel by reviewing the novels' intrinsic structure, (5) making a description and a summary relating to novel intrinsic structure, (6) analyzing family education values in novels by reviewing the author's background, (7) making a working table related to recapitulation numbers of data observing family education values in novels by reviewing the author's background, (8) making a summary, (9) analyzing family education values in the novelsby reviewing the social background, (10) making a working 
table related to recapitulation numbers of data observing family education values in the novels by reviewing the social background, (11) making a summary, (12) analyzing family education values in the novels by reviewing author's world view, (13) making a working table related to recapitulation numbers of data observing family education values in the novels by reviewing the author's world view, (14) making a summary.

In this data analysis procedures, the researcher also makes comparison. The researcher compares the values of family education in the novels reviewed through the novel's intrinsic structure, the author's background, social background, and the author's world view, elaborates them, then makes summaries in table form.

\section{RESULTS AND DISCUSSION}

Family Education Values in Kirana Kejora's Novels Reviewed by Novel's Intrinsic Structure

In the three novels by Kirana Kejora, thirteen family education values are firstly reviewed through novel intrinsic structure. Those family education values consist of diligent to worship, honest, respect, unanimous, having achievement, mandate, brave, independent, proportional, take care of self, affection, prelude other people, and fair.

From the analysis, it can be concludes that Kejora expresses her thoughts on her novels, including the novel intrinsic structure. Elements of novel intrinsic structure from a unity until positive messages related to family education values are got. The readers can comprehend about family education valuesby themselves through the relation of novel intrinsic structure.

The themes of Kirana Kejora's novels (Bintang Anak Tuhan, Air Mata Terakhir Bunda, Ayah Menyayangi Tanpa Akhir) are family affection. The characters and its characterizations have domination about affection and the stories always tell about single parents and their children. The plots of the stories show about the sincere struggles between single parents and their children in this life.

Table 1. Family Education Values in Kirana Kejora's Novels Reviewed by Novel Intrinsic Structures

\begin{tabular}{|c|c|c|c|c|}
\hline $\begin{array}{l}\text { The Title of the } \\
\text { Novels and the } \\
\text { Result of Quotation }\end{array}$ & No. & Family Education Values & Frequency & Percentage \\
\hline \multirow{13}{*}{$\begin{array}{c}\text { Bintang Anak } \\
\text { Tuhan } \\
\text { (50 quotations) }\end{array}$} & 1. & Diligent to worship & 8 & $10 \%$ \\
\hline & 2. & Honest & 1 & $2 \%$ \\
\hline & 3. & Respect & 4 & $8 \%$ \\
\hline & 4. & Unanimous & 2 & $4 \%$ \\
\hline & 5. & Having achievement & 1 & $2 \%$ \\
\hline & 6. & Mandate & 3 & $6 \%$ \\
\hline & 7. & Brave & 4 & $8 \%$ \\
\hline & 8. & Independent & 3 & $6 \%$ \\
\hline & 9. & Proportional & 2 & $4 \%$ \\
\hline & 10. & Take care of self & 1 & $2 \%$ \\
\hline & 11. & Affection & 15 & $30 \%$ \\
\hline & 12. & Prelude Other People & 5 & $10 \%$ \\
\hline & 13. & Fair & 1 & $2 \%$ \\
\hline \multirow{3}{*}{$\begin{array}{c}\text { Air Mata Terakhir } \\
\text { Bunda } \\
\text { (63 quotations) }\end{array}$} & 1. & Diligent to worship & 9 & $15 \%$ \\
\hline & 2. & Honest & 4 & $6 \%$ \\
\hline & 3. & Respect & 5 & $8 \%$ \\
\hline
\end{tabular}




\begin{tabular}{|c|c|c|c|c|}
\hline & 4. & Unanimous & 4 & $6 \%$ \\
\hline & 5. & Having achievement & 9 & $15 \%$ \\
\hline & 6. & Mandate & 4 & $6 \%$ \\
\hline & 7. & Brave & 1 & $2 \%$ \\
\hline & 8. & Independent & 3 & $4 \%$ \\
\hline & 9. & Proportional & 1 & $2 \%$ \\
\hline & 10. & Take care of self & 5 & $8 \%$ \\
\hline & 11. & Affection & 15 & $23 \%$ \\
\hline & 12. & Prelude Other People & 1 & $2 \%$ \\
\hline & 13. & Fair & 2 & $3 \%$ \\
\hline \multirow{13}{*}{$\begin{array}{c}\text { Ayah Menyayangi } \\
\text { Tanpa Akhir (65 } \\
\text { quotations) }\end{array}$} & 1. & Diligent to worship & 2 & $4 \%$ \\
\hline & 2. & Honest & 0 & $0 \%$ \\
\hline & 3. & Respect & 6 & $11 \%$ \\
\hline & 4. & Unanimous & 3 & $5 \%$ \\
\hline & 5. & Having achievement & 1 & $2 \%$ \\
\hline & 6. & Mandate & 3 & $5 \%$ \\
\hline & 7. & Brave & 9 & $16 \%$ \\
\hline & 8. & Independent & 4 & $8 \%$ \\
\hline & 9. & Proportional & 2 & $4 \%$ \\
\hline & 10. & Take care of self & 3 & $5 \%$ \\
\hline & 11. & Affection & 18 & $33 \%$ \\
\hline & 12. & Prelude Other People & 3 & $5 \%$ \\
\hline & 13. & Fair & 1 & $2 \%$ \\
\hline
\end{tabular}

\section{Family Education Values in Kirana Kejora's Novels Reviewed by Author's Background}

In Bintang Anak Tuhan's novel, there are five author backgrounds identified by the researcher. The five author backgrounds are her early-age marriage status, having a daughter, having mother who suffers lung disease, and caring of people who suffers HIV/AIDS. From those author's backgrounds, the researcher identifies eight family education values, namely diligent to worship, unanimous, having achievement, brave, independent, proportional, take care of self, and affection. In Air Mata Terakhir Bunda's novel, there are six backgrounds of the author. Those six backgrounds are a mother who is a strong, a mother as a single parent whose ex-husband has get married again, diligence to worship since she was a child, the existence of effort to create fairness in family, a mother as single parent who puts her children's education first, and a mother who has ever lived in Sidoarjo. From the reviews of those backgrounds, the researcher gets six family education values, including diligent to worship, having achievement, brave, take care of self, affection, and fair. In Ayah Menyayangi Tanpa Akhir, it can be concluded that there are six author backgrounds. The author backgrounds are about children's birthday celebration in orphanage, a boy who is like a hawk, parents who are full of affection, inspiration about history and archeology, a life that is usually filled by putting others first, and harmony in family. From the reviews of those backgrounds, the researcher identifies five family education values, involving unanimous, mandate, brave, affection, and prelude other people. 
Table 2. Family Education Values in Kirana Kejora's Novels Reviewed by Author's Background

\begin{tabular}{|c|c|c|c|c|}
\hline $\begin{array}{c}\text { The Title of the Novels } \\
\text { and the Result of } \\
\text { Quotation }\end{array}$ & No. & Family Education Values & Frequency & Percentage \\
\hline \multirow{13}{*}{$\begin{array}{l}\text { Bintang Anak Tuhan } \\
\text { (24 quotations) }\end{array}$} & 1. & Diligent to worship & 4 & $17 \%$ \\
\hline & 2. & Honest & 0 & $0 \%$ \\
\hline & 3. & Respect & 0 & $0 \%$ \\
\hline & 4. & Unanimous & 2 & $8 \%$ \\
\hline & 5. & Having achievement & 2 & $8 \%$ \\
\hline & 6. & Mandate & 0 & $0 \%$ \\
\hline & 7. & Brave & 2 & $8 \%$ \\
\hline & 8. & Independent & 2 & $8 \%$ \\
\hline & 9. & Proportional & 2 & $1 \%$ \\
\hline & 10. & Take care of self & 4 & $17 \%$ \\
\hline & 11. & Affection & 6 & $26 \%$ \\
\hline & 12. & Prelude Other People & 0 & $0 \%$ \\
\hline & 13. & Fair & 0 & $0 \%$ \\
\hline \multirow{13}{*}{$\begin{array}{c}\text { Air Mata Terakhir Bunda } \\
\text { (14 quotations) }\end{array}$} & 1. & Diligent to worship & 2 & $14 \%$ \\
\hline & 2. & Honest & 0 & $0 \%$ \\
\hline & 3. & Respect & 0 & $0 \%$ \\
\hline & 4. & Unanimous & 0 & $0 \%$ \\
\hline & 5. & Having achievement & 4 & $30 \%$ \\
\hline & 6. & Mandate & 0 & $0 \%$ \\
\hline & 7. & Brave & 2 & $15 \%$ \\
\hline & 8. & Independent & 0 & $0 \%$ \\
\hline & 9. & Proportional & 0 & $0 \%$ \\
\hline & 10. & Take care of self & 5 & $8 \%$ \\
\hline & 11. & Affection & 15 & $23 \%$ \\
\hline & 12. & Prelude Other People & 1 & $2 \%$ \\
\hline & 13. & Fair & 2 & $3 \%$ \\
\hline \multirow{13}{*}{$\begin{array}{c}\text { Ayah Menyayangi Tanpa } \\
\text { Akhir (16 quotations) }\end{array}$} & 1. & Diligent to worship & 0 & $0 \%$ \\
\hline & 2. & Honest & 0 & $0 \%$ \\
\hline & 3. & Respect & 0 & $0 \%$ \\
\hline & 4. & Unanimous & 4 & $26 \%$ \\
\hline & 5. & Having achievement & 0 & $0 \%$ \\
\hline & 6. & Mandate & 2 & $11 \%$ \\
\hline & 7. & Brave & 2 & $11 \%$ \\
\hline & 8. & Independent & 0 & $0 \%$ \\
\hline & 9. & Proportional & 0 & $0 \%$ \\
\hline & 10. & Take care of self & 0 & $0 \%$ \\
\hline & 11. & Affection & 4 & $26 \%$ \\
\hline & 12. & Prelude Other People & 4 & $26 \%$ \\
\hline & 13. & Fair & 0 & $0 \%$ \\
\hline
\end{tabular}


From the analysis, it can be known that Kejora got married because of affection, so she expresses it on characters named Hanum and Agung who get married young because of affection in Bintang Anak Tuhan's novel. Here, Kejora was inspired by Bunga who always keeps her mother's feelings, so Kejora creates a character named Bintang who keeps himself to not making Hanum sad. Besides, Bintang who is also a person who always beside people with HIV/AIDS and $T B C$. Moreover, Kejora was inspired by her mother who keeps herself away from Kejora in order to keep Kejora safe and is not contaminated by her lung disease. In addition, there are also people with HIV/AIDS who surrender and try to get close to God. Therefore, the characters Hanum and Bintangshow the value diligent to worship. In Air Mata Terakhir Bunda's novel, it can be known that Kejora does not want to be a weak mother through the character named Delta who never wants to be looked sad by her mother. Kejora's ex-husband has got married again, and Kejora never slanders her husband so it implies affection without hope. Sriyani character is also created based on Kejora's condition. Kejora is taught to be diligent to worship since she was a child by her mother. Therefore, based on those experiences, Delta is taught to be diligent to worship by Sriyaniin Air Mata Terakhir Bunda's novel.

Ayah Menyayangi Tanpa Akhir's novel tells about Mada who cares of the orphanage. He always spreads the happiness there. This story is based on the author's background for celebrating Bunga's birthday in orphanage by giving gifts. Kejora often calls Arga as 'Elang' - which means 'hawk' in English. Therefore, Argais taught to be as strong as a hawk and the fact is Arga can be strong. Kejora manifests that condition on Juna character who suggests Mada to learn from a hawk until Mada can be a strong figure. The figure of Kejora's parents, especially Kejora's father, is full of affection so that Kejora can understand what affection is.

\section{Family Education Values in Kirana Kejora's Novels Reviewed by Social Background}

In Bintang Anak Tuhan's novel, there are six social backgrounds found by the researcher. Those are the social backgrounds about people's slanted paradigm towards people with HIV/AIDS, the existence of people with HIV/AIDS who are contaminated HIV/AIDS through drugs, threat of HIV/AIDS to life, there still exist people with HIV/AIDS who has strong souls, there still exist normal people who accept and help people with HIV/AIDS, and the existence of people with HIV/AIDS who realize to keep themselves. From those social backgrounds, the researcher gets eleven family education values, namely diligent to worship, honest, respect, unanimous, having achievement, mandate, brave, independent, proportional, take care of self, and affection. In Air Mata Terakhir

Bunda's novel, there are four social backgrounds found consisting of social background of Sidoarjo people who are impassioned, the existence of matchmaking in Sidoarjo people, the condition of Sidoarjo people related to mud disaster of Lapindo, and social background about en event to get rid of the children's trauma because of mud disaster of Lapindo. By reviewing social backgrounds, the researcher gets six family education values contained in Air Mata Terakhir Bunda's novel, namely diligent to worship, brave, mandate, independent, proportional, and affection. Then, in Ayah Menyayangi Tanpa Akhir's novel, there are five social backgrounds found, those are social backgrounds about general condition of a father as a single parent in Indonesia, matchmaking in family, international marriage, father's struggles as a single parent, and the existence of men who have social carefulness. From those social backgrounds, the researcher gets six family education values, includinghonest, respect, independent, affection, and prelude other people. 
Table 3. The Results of Family Education Values in Kirana Kejora's Novels Reviewed by Social Background

\begin{tabular}{|c|c|c|c|c|}
\hline $\begin{array}{l}\text { The Title of the } \\
\text { Novels and the } \\
\text { Result of Quotation }\end{array}$ & No. & Family Education Values & Frequency & Percentage \\
\hline \multirow{13}{*}{$\begin{array}{l}\text { Bintang Anak Tuhan } \\
\text { (16 quotations) }\end{array}$} & 1. & Diligent to worship & 4 & $10 \%$ \\
\hline & 2. & Honest & 0 & $2 \%$ \\
\hline & 3. & Respect & 0 & $8 \%$ \\
\hline & 4. & Unanimous & 0 & $4 \%$ \\
\hline & 5. & Having achievement & 2 & $2 \%$ \\
\hline & 6. & Mandate & 0 & $6 \%$ \\
\hline & 7. & Brave & 2 & $8 \%$ \\
\hline & 8. & Independent & 0 & $6 \%$ \\
\hline & 9. & Proportional & 9 & $4 \%$ \\
\hline & 10. & Take care of self & 6 & $2 \%$ \\
\hline & 11. & Affection & 2 & $30 \%$ \\
\hline & 12. & Prelude Other People & 0 & $10 \%$ \\
\hline & 13. & Fair & 0 & $2 \%$ \\
\hline \multirow{13}{*}{$\begin{array}{c}\text { Air Mata Terakhir } \\
\text { Bunda (22 } \\
\text { quotations) }\end{array}$} & 1. & Diligent to worship & 4 & $15 \%$ \\
\hline & 2. & Honest & 0 & $6 \%$ \\
\hline & 3. & Respect & 0 & $8 \%$ \\
\hline & 4. & Unanimous & 0 & $6 \%$ \\
\hline & 5. & Having achievement & 0 & $0 \%$ \\
\hline & 6. & Mandate & 2 & $8 \%$ \\
\hline & 7. & Brave & 2 & $8 \%$ \\
\hline & 8. & Independent & 6 & $27 \%$ \\
\hline & 9. & Proportional & 4 & $19 \%$ \\
\hline & 10. & Take care of self & 0 & $0 \%$ \\
\hline & 11. & Affection & 4 & $19 \%$ \\
\hline & 12. & Prelude Other People & 0 & $0 \%$ \\
\hline & 13. & Fair & 0 & $0 \%$ \\
\hline \multirow{13}{*}{$\begin{array}{c}\text { Ayah Menyayangi } \\
\text { Tanpa Akhir ( } 20 \\
\text { quotations) }\end{array}$} & 1. & Diligent to worship & 0 & $0 \%$ \\
\hline & 2. & Honest & 2 & $10 \%$ \\
\hline & 3. & Respect & 2 & $10 \%$ \\
\hline & 4. & Unanimous & 0 & $0 \%$ \\
\hline & 5. & Having achievement & 0 & $0 \%$ \\
\hline & 6. & Mandate & 0 & $0 \%$ \\
\hline & 7. & Brave & 0 & $0 \%$ \\
\hline & 8. & Independent & 2 & $10 \%$ \\
\hline & 9. & Proportional & 0 & $0 \%$ \\
\hline & 10. & Take care of self & 0 & $0 \%$ \\
\hline & 11. & Affection & 8 & $40 \%$ \\
\hline & 12. & Prelude Other People & 2 & $10 \%$ \\
\hline & 13. & Fair & 4 & $20 \%$ \\
\hline
\end{tabular}


In Bintang Anak Tuhan's novel, it is discussed that people with HIV/AIDS are marginalized, so they need affection. The families of people with HIV/AIDS keep fighting for people with HIV/AIDS to get education even if it is through home schooling. Family education value for being independent are based on people with HIV/AIDS who are finally independent, and it is manifested through Hanum's character who is independent and powerful. The effort to take care of oneself appears through families of people with HIV/AIDS who do not let their children to feel tired.

In Air Mata Terakhir Bunda's novel, it discusses about Kejora's observations towards Sidoarjo people who are full of power, for instance, there exist people who earn money by selling Kupang rice cake, and are full of intention. Sriyani's character also gives family education value for selfreliance to her children by working as a Kupang rice cake seller, and not hoping other people's mercy. Sidoarjo's children generally get matchmaking trust from their parents to get married with men or women chosen by their parents. The situation is described through Sriyani's character. In Ayah Menyayangi Tanpa Akhir's novel, it is also discussed that affection appears from father's figures as a single parent in Indonesia who are great and full of affection to their children. They can also become a figure of mother for their children. That condition is described through Juna's character who gives affection to Mada as well as a father and a mother give to their children. Besides, there also exists family education value for self-reliance, which is synthesized by a father who is also able to do mother's jobs. In this case, fathers can also teach their children to learn to live independently.

\section{Family Education Values in Kirana Kejora's Novels Reviewed by Author's World View}

In Bintang Anak Tuhan's novel, there are three author's view point towards world identified to influence the novel. The author's world view towards suffer is power, it is not easy for parents with HIV/AIDS to have children who also suffer HIV/AIDS. People with HIV/AIDS are not the ones who are useless. By reviewing the author's world view, the researcher gets four family education values, namely diligent to worship, brave, honest, and affection. In Air Mata Terakhir Bunda's novel, the researcher gets four author's world view, involving the author world view for confidence of people who were attacked by mud disaster of Lapindo to resurrect, mothers as a single parent, mother as a little God, and the philosophy of the novel's title Air Mata Terakhir Bunda. By reviewing the author's world view, the researcher gets three family education values, those are diligent to worship, brave, and affection. Next, in Ayah Menyayangi Tanpa Akhir's novel, specifically the researcher gets the author's world view, including the author's world view about suffer is power, part of men traditional-clothes from Central Java, the father as a single parent in young age, children's views are sustenance, family is a nation foundation, the single father who does everything to his children, and the father is the owner of hidden love. By reviewing those viewpoints towards love, the researcher gets six family education values, those are diligent to worship, having achievement, brave, proportional, take care of self, and affection. 
Table 4. The Results of Family Education Values in Kirana Kejora's Novels Reviewed by Author's World View

\begin{tabular}{|c|c|c|c|c|}
\hline $\begin{array}{l}\text { The Title of the } \\
\text { Novels and the } \\
\text { Result of Quotation }\end{array}$ & No. & Family Education Values & Frequency & Percentage \\
\hline \multirow{13}{*}{$\begin{array}{c}\text { Bintang Anak Tuhan } \\
\text { (14 quotations) }\end{array}$} & 1. & Diligent to worship & 2 & $14 \%$ \\
\hline & 2. & Honest & 2 & $14 \%$ \\
\hline & 3. & Respect & 0 & $0 \%$ \\
\hline & 4. & Unanimous & 0 & $0 \%$ \\
\hline & 5. & Having achievement & 0 & $0 \%$ \\
\hline & 6. & Mandate & 0 & $0 \%$ \\
\hline & 7. & Brave & 6 & $43 \%$ \\
\hline & 8. & Independent & 0 & $0 \%$ \\
\hline & 9. & Proportional & 0 & $0 \%$ \\
\hline & 10. & Take care of self & 0 & $0 \%$ \\
\hline & 11. & Affection & 4 & $29 \%$ \\
\hline & 12. & Prelude Other People & 0 & $0 \%$ \\
\hline & 13. & Fair & 0 & $0 \%$ \\
\hline \multirow{13}{*}{$\begin{array}{c}\text { Air Mata Terakhir } \\
\text { Bunda }(10 \\
\text { quotations })\end{array}$} & 1. & Diligent to worship & 2 & $20 \%$ \\
\hline & 2. & Honest & 0 & $0 \%$ \\
\hline & 3. & Respect & 0 & $0 \%$ \\
\hline & 4. & Unanimous & 0 & $0 \%$ \\
\hline & 5. & Having achievement & 0 & $0 \%$ \\
\hline & 6. & Mandate & 0 & $0 \%$ \\
\hline & 7. & Brave & 2 & $20 \%$ \\
\hline & 8. & Independent & 0 & $0 \%$ \\
\hline & 9. & Proportional & 0 & $0 \%$ \\
\hline & 10. & Take care of self & 0 & $0 \%$ \\
\hline & 11. & Affection & 6 & $60 \%$ \\
\hline & 12. & Prelude Other People & 0 & $0 \%$ \\
\hline & 13. & Fair & 0 & $0 \%$ \\
\hline \multirow{13}{*}{$\begin{array}{c}\text { Ayah Menyayangi } \\
\text { Tanpa Akhir ( } 36 \\
\text { quotations) }\end{array}$} & 1. & Diligent to worship & 10 & $27 \%$ \\
\hline & 2. & Honest & 2 & $6 \%$ \\
\hline & 3. & Respect & 0 & $0 \%$ \\
\hline & 4. & Unanimous & 0 & $0 \%$ \\
\hline & 5. & Having achievement & 4 & $11 \%$ \\
\hline & 6. & Mandate & 0 & $0 \%$ \\
\hline & 7. & Brave & 8 & $22 \%$ \\
\hline & 8. & Independent & 0 & $0 \%$ \\
\hline & 9. & Proportional & 2 & $6 \%$ \\
\hline & 10. & Take care of self & 2 & $6 \%$ \\
\hline & 11. & Affection & 8 & $22 \%$ \\
\hline & 12. & Prelude Other People & 0 & $0 \%$ \\
\hline & 13. & Fair & 0 & $0 \%$ \\
\hline
\end{tabular}


In Bintang Anak Tuhan's novel, it is discussed that family can be friends with suffer and precisely be strong because of the suffer itself. So, in that family, there can manifest family education values for being brave. In Air Mata Terakhir Bunda's novel, it discusses the author's world view towards love for a single mother, so there is family education value for affection. That value is discussed through a single mother who gives affection abundantly to her children, because children actually need a figure of father beside a figure of mother.

\section{Comparison of Family Education Values between Kirana Kejora's Novels}

The analysis about family education values in Kirana Kejora's novels were reviewed by the novel intrinsic structure, author's background, social background, and author's world view. The analysis results of the three novels were then compared to each other. As results, it was revealed that Kirana Kejora's novels contain family education values which imply how close a relationship between a single parent with his or her childrenis. Specifically, family education value for affection is really salient. Therefore, it can be synthesized that these Kirana Kejora's novels themed family are fully filled by affection among parents with children.

\section{CONCLUSION}

This research results five conclusions, including: (1) thirteen family education values in Bintang Anak Tuhan's and Air Mata Terakhir Bunda's novels were reviewed through six novel intrinsic structures, whereas twelve family education values in Ayah Menyayangi Tanpa Akhir's novel were reviewed through six novel intrinsic structures, (2) eight family education values in Bintang Anak Tuhan's novel were reviewed through five author's backgrounds, six family education values in Air Mata Terakhir Bunda's novel were reviewed through six author's backgrounds, five family education values in Ayah Menyayangi Tanpa Akhir's novel were reviewed through six author's backgrounds, (3) eleven family education values in Bintang Anak Tuhan's novel were reviewed through six social backgrounds, six family education values in Air Mata Terakhir Bunda's novel were reviewed through four social backgrounds, four family education values in Ayah Menyayangi Tanpa Akhir's novel were reviewed through five social backgrounds, (4) four family education values in Bintang Anak Tuhan's novel were reviewed through three author's world views, three family education values in Air Mata Terakhir Bunda's novel were reviewed through four author's world views, six family education values in Ayah Menyayangi Tanpa Akhir's novel were reviewed through seven author's world views, and also (5) there are similarities and differences of family education values between Kirana Kejora's novels. The main point is, the affection has big role above all family education values. It means that Kejora as the author wants to tell the readers that the families that only consist of a single parent and their children still have affection like another complete families.

\section{REFERENCES}

Dosse, F., translated by Deborah Glassman. (1998). History of structuralism (Volume 2). Minnesota: University of Minnesota Press.

Eagleton, T. (1996). Literary theory: An introduction. Oxford: Blackwell Publishing.

Endraswara, S. (2008). Metodologi penelitian sastra: Epistemologi, model, teori, dan aplikasi. Yogyakarta: MedPress.

Endraswara, S. (2011). Metodologi penelitian sosiologi sastra. Yogyakarta: CAPS.

Endraswara, S. (2012). Teori pengkajian sosiologi sastra. Yogyakarta: UNY Press.

Goldmann, L. (1977). Toward a sociology of the novel. London: Tavistock Publications.

Lestari, S. (2014). Psikologi keluarga: Penanaman nilai dan penanganan konflik dalam keluarga. Jakarta: Kencana.

Railton, P. (2003). Facts and values: Essays towards a morality of consequence. Cambridge: Cambridge University Press. 
Wulan Wahyuning Ratri, Emzir, \& Ninuk Lustyantie

Family education values in Kirana Kejora's novels: Genetic structural research

Stanton, R., translated by Sugihastuti \& Rossi Abi Al Irsyad. (2007). Teori fiksi Robert Stanton. Yogyakarta: Pustaka Pelajar.

Syafrial. (2014). Problematika bahan ajar bidang sastra dalam buku wajib pelajaran Bahasa Indonesia kurikulum 2013 di Sekolah Menengah. Jurnal Bahasa, 9(2), 73-75.

Syamsi, H., translated by Umar Mujtahid. (2014). Modern Islamic parenting: Cara mendidik anak masa kini dengan metode Nabi. Solo: Aisar Publishing. 